IRSH 62 (2017), pp. 50I-508 doi:I0.10I7/S0020859017000372

(C) 2017 Internationaal Instituut voor Sociale Geschiedenis

\title{
Studying Migration on a Global Scale
}

\author{
LyNN HOLLEN LEES \\ University of Pennsylvania \\ I 3 Dubring Wing, Philadelphia, PA I9I30, USA \\ E-mail: lhlees@sas.upenn.edu
}

Growing resentment against refugees and widespread fears of immigrants give added importance to the messages of Globalising Migration History. Indeed, if academic works had greater influence and broader audiences, this global framework, which draws all of Eurasia into a common typology of quantified movements and periodicity, could cool popular passions with its wave of rational argument about the ubiquity of cross-cultural migration. But that hope is no doubt absurdly optimistic. Nevertheless, the messages that movement is normal and that immigrants integrate in a society or move on deserve repetition.

Jan and Leo Lucassen's recent books and articles are an important contribution to a recent wave of migration studies that situate that field solidly within world history. ${ }^{\mathrm{I}}$ Too much past research on migration operated relatively narrowly within one national or continental space, neglecting similar movements elsewhere and avoiding linkage to larger debates about social change and economic development. This volume tackles the issue of comparison straightforwardly, by creating a measurement of cross-cultural migration that can be applied in regions where states collected statistics similar to those created by European polities. Strong states - whether nations, kingdoms, or empires - have proved to be the units most easily brought within this analytical frame, which fits uneasily with mobile regions, such as the islands of Southeast Asia and the Malay peninsula, during periods when they lacked strong political structures.

I. J. Lucassen, L. Lucassen, and P. Manning (eds), Migration History in World History: Multidisciplinary Approaches (Leiden and Boston, MA, 20I0); J. Lucassen and L. Lucassen, "From Mobility Transition to Comparative Global Migration History", The Journal of Global History, 6:2 (20I I), pp. 299-307; J. Lucassen and L. Lucassen (eds), Globalising Migration History: The Eurasian Experience (I6th-2 Ist Centuries) (Leiden and Boston, MA, 2014); L. Lucassen and J. Lucassen, "The Strange Death of Dutch Tolerance: The Timing and Nature of the Pessimist Turn in the Dutch Migration Debate", The Journal of Modern History, 87:I (201 5), pp. 72-10I; P. Manning, Migration in World History, 2nd ed. (Abingdon and New York, 20I3); D. Hoerder, Cultures in Contact: World Migrations in the Second Millennium (Durham, NC, 2002); D. Gabaccia and D. Hoerder (eds), Connecting Seas and Connected Ocean Rims: Indian, Atlantic, and Pacific Oceans and China Seas Migrations from the I830s to the I930s (Leiden and Boston, MA, 20II); L.P. Moch, "Connecting Migration and World History: Demographic Patterns, Family Systems and Gender”, International Review of Social History, 52:I (2007), pp. 97-I04. 
The Lucassens's arguments have both a softer and a harder form. On the one hand, they are merely offering "a method and a typology", which permits comparison over time and space, allowing migration to be seen as an "important variable" for "global comparative history". Their flexibility in relating their CCMR to "territories" rather than states opens the door to smaller as well as larger geographical units. ${ }^{2}$ Not only are their definitions and sources open to public scrutiny, their six categories of activity immigration, emigration, rural-to-urban moves, colonization, seasonal, and temporal multi-annual moves - are widely applicable, although not universally inclusive. Moreover, they welcome refinements and suggestions. Who could object to this even-handed attempt to refine migration studies by providing a common foundation for further work? Their numbers provide an excellent starting point for analysing comparative patterns of migration, whatever the final arguments that emerge from broadly based research.

At the same time, the authors have much larger goals in mind. They take aim at major social science theories, such as the idea of a Mobility Transition as posited by Zelinsky in I97I, and they want to contribute to "major debates in global history". "Their arguments, like much global history dealing with the past 500 years, concern relative social and economic performance in the world's drive to modernity, a very contemporary preoccupation. Clearly, migration matters, but exactly how and why remain elusive, and there is no agreement upon the precise framework within which that movement ought to be viewed. Institutional economic history and historical sociology come together in their work, which owes a lot to the formulations of Charles Tilly, Patrick Manning, Douglas North, and Kenneth Pomeranz, as well as to the notion of path dependence. ${ }^{4}$ Using the assumption that cross-cultural migration encourages innovation, they conclude that the "composition of the types of migration" matters more for economic growth than the "sheer levels of mobility", and they distinguish between the more coercive and the more commercial institutional regimes that shape patterns of movement at the national level, arguing for the greater efficacy of more flexible, commercial paths. It should be noted, however, that predominantly commercial regimes, such as that of Great Britain or the Netherlands, could permit highly coercive migrations outside their national

2. Lucassen and Lucassen, Globalising Migration History, pp. I4, 428.

3. W. Zelinsky, "The Hypothesis of the Mobility Transition", The Geographical Review, 6r:2 (1971), pp. 219-249; Lucassen and Lucassen, Globalising Migration History, p. 417.

4. Charles Tilly, Coercion, Capital and European States, AD 990-I992 (Cambridge, 1990); P. Manning, "Cross-Community Migration: A Distinctive Human Pattern", Social Evolution E History, 5:2 (2006), pp. 24-54; Manning, Migration in World History; D. North, Institutions, Institutional Change and Economic Performance (Cambridge, 2002); K. Pomeranz, The Great Divergence: China, Europe, and the Making of the Modern World Economy (Princeton, NJ, 2000). 5. Lucassen and Lucassen, Globalising Migration History, pp. 427-428. 
borders - slavery and indentured servitude, for example - and that a state such as Japan could clamp down hard on immigration and emigration while permitting much internal migration. The clarity of a binary typological distinction breaks down when migration regimes are examined in detail. This is an important argument as well as an overdue call for migration to be considered seriously by theorists of social and economic change in the modern period. At the same time, it is only one arena of questions that could be posed about the impact of the intensive movement of peoples that has characterized many societies for centuries. Contributions to the volume on China, Russia, and Japan survey key Eurasian examples but omit the Middle East and much of central Asia.

Sources, typology, and assumptions work together in this precise formulation to privilege states and institutions as the controlling parameters of migration in the modern and early modern periods. Although state power over borders and citizenship is undeniable in recent times, the floods and unknown numbers of "illegal" immigrants and the undocumented networks of movement by ethnic or religious groups show both the limits of state power and of administrative sources. What of other decision makers? Think of the power of households and individuals, who choose whom to send away, whether or not to move, and what destination to select. From the standpoint of those who move, migration can have very different dynamics than those of a macro-level system defined by policy edicts, state borders, and formal regions. Lewis H. Siegelbaum and Leslie Page Moch distinguish between migration regimes, organized by the state, and the repertoires of migrants who developed their own networks within, or sometimes in opposition to, state regimes. ${ }^{6}$ Relating the periodicities and patterns of individual migrant decision-making to state-level preoccupations requires a weaving together of two very different stories whose linkages require specification in relation to local conditions. While Globalising Migration History calls for micro-level studies to complement macro-level data with information on the human capital transferred by cross-cultural migrants, this research is intended to be complementary to the study of CCMR and its component parts, which privileges the migration story at the macro level. The question of how migrants' repertoires are integrated with migration regimes needs more attention.

It is worth pausing to consider the implications of the cross-cultural migration rate, intended to differentiate moves that have a higher potential for producing social or cultural changes from those less likely to do so. Although the Lucassens sensibly reject as unproductive the simple dichotomies that have excluded important types of mobility from many 
migration studies, their interest in relating migration to social change has led them to make the crossing of a cultural boundary the characteristic that differentiates migration from mere movement, which usually goes unrecorded and is assumed not to matter - at least, not very much. One cannot assume with certainty, however, for any individual that a change of cultures follows simply from the fact of a new address. Cultural change might be the result, on average, for the thousands of new city dwellers who arrive annually and stay long enough to be counted, but consider the cases of the tramping artisan who remains within a circle of similar small towns or of a female domestic from the countryside who might be recorded in a census but remain at a job very briefly before returning to her village. What of elderly parents who do not change language, diet, or habits after joining children in a town? And what of new city dwellers who move from other similar cities? Each of these cases counts as a migratory event, but one can quibble about the depth of their cultural impacts. Moreover, the meaning of types of moves varies over time and among societies. With the urbanization of the countryside that follows its penetration by mass media, access to cheap transportation, and rising incomes, the rural-to-urban gap diminishes. Similar migratory events can have different cultural effects depending on the characteristics of individuals and places. Moreover, the CCMR ignores the impact of common movements among rural areas which might well have cross-cultural implications. Exogamous marriage patterns, in which women joined different groups and villages after they wed, were a common mechanism of cross-communal influence unrelated to state migration regimes, and these relocations are normally not included in the CCMR. Discussions of gender and its influence in different migratory systems need to be added soon to the Lucassens's model. These concerns are not an argument against the utility of calculating cross-cultural migration rates, but a caveat about the meaning of what is captured in the concept of cross-cultural and the analytical weight being put on it. Macro-level data can specify the magnitude of migratory moves, but not their impacts.

One consistent theme in the comparisons permitted by calculations of CCMR is the important contribution of urbanization to national patterns of movement. From the sixteenth century, rural-to-urban movement made up a significant share of all migratory moves in China and Europe, as well as in Japan since the seventeenth century. When combined with national urbanization rates, the CCMR is an important tool for quantifying the relative importance of movement into cities as it differed among regions. Figures for state urbanization levels send signals different from those implied by the relative importance at any given period of particular cities or of overall rural-to-urban movement. It should be remembered that some national sources (and researchers) set the bar of 10,000 residents as a threshold for city size, neglecting smaller units that can be of great importance, particularly in the early phases of an upswing in urbanization, when 
movement into small towns and newly established industrial settlements can be intense. The bigger the overall population size of a territory, the more numerous and larger the cities that are required to raise its urbanization level. A rising share of urbanization in a CCMR signals changes in the relative position of cities as targets of opportunity, but the reasons for the change can vary from devastation in the countryside to rising urban wages and opportunities. It is important, as the Lucassens suggest, to underpin a comparison of national rates with institutional and macroeconomic analyses in order to understand the meaning of rural-to-urban movements.

I have found myself worrying about types of moves not captured by the CCMR, which would be relevant for interpretations of overall patterns of movement. The CCMR is designed to capture the probability that an individual will have made at least one cross-cultural migration within his or her lifetime, but some make many moves, most of which would not be recorded in the aggregate figures for urban growth on which the Lucassens base their calculations. Urban populations briefly included hundreds of thousands of young people who moved into one town temporarily, and then another, and perhaps another, but decadal censuses are too crude a tool to capture these actions. ${ }^{7}$ What is the likelihood that at least one of an individual's several temporary moves will be counted? Limited and episodic state record keeping can pick up only some migratory events, and double counting cannot be excluded. Would not the soldier who emigrated to another country after demobilization be counted twice in a state's CCMR? What of the tramping artisan who eventually settled in a city permanently? The CCMR does not calculate an overall rate of movement, nor does it capture timing in terms of a life cycle or periodicity. While the categories of seasonal, temporal multi-annual, and rural-to-urban migration catch several important sorts of relocation by young people, their magnitudes are difficult to determine given the way that most state statistics are compiled, and their boundaries are fuzzy. People in motion are notoriously hard to track in many political systems - particularly those of more open and less directly coercive societies. In any case, individuals often have strong incentives to stay out of the gaze of the state. Perhaps those missed or double counted are too few to influence overall trends, but the sizes of these two groups will not be identical in all states and record-keeping systems. Moreover, they will vary over time. The question of whether particular sets of sources undercount groups of significance needs to be faced more explicitly. What can be said about relative degrees of uncertainty and error?

I wonder also about the implication that the relative importance of a migration can be estimated by its size. ${ }^{8}$ While the absolute number of cross-cultural 
migrants matters not only to authorities and to local communities, cultural impact can be influenced also by qualitative issues disproportionate to the size of the group. Think about the response of Southeast Asian populations to the arrival of Muslim merchants and wandering Sufi mystics in the fourteenth and fifteenth centuries, when local rulers adopted a new faith. ${ }^{9}$ Even if huntergatherer, nomadic, and transhumant populations account for a small share of European and Asian state populations in the modern period, they constituted a major share of residential groups in other places and earlier times - pre-colonial North America or parts of sub-Saharan Africa, for example. When measured in terms of regional population totals, their share could have been dominant. As a concept, the CCMR does less well with what have become marginal peoples and forms of movement than it does with the structures of modern migrations in regions where strong states emerged. The discussion by Atsushi Ota of maritime traders and the sea peoples of the larger Malay Archipelago and the analysis by Mireille Mazard of Lisu migrations in the borderland areas of China, Burma, and Thailand highlight the difficulties of determining not only migration scales, but also its cross-cultural impacts where groups operated largely outside the effective control of state administrations. ${ }^{\text {IO }}$

Migration is, by definition, movement in space, whether across a national boundary or within a state. Distance matters, as do directions and destinations. A next obvious step in globalizing migration history should be plotting the contours of migration networks, which has been done by contributors to this volume in larger research projects. ${ }^{I I}$ Globalising Migration History is noteworthy, however, for its few maps and the lack of linkage between the CCMR and any attempt to plot spatially the movements counted. Granted, a globe covered with crisscrossing arrows would confuse more than enlighten, but there are alternatives. Maps comparing the relative weights of cross-cultural migration to a state at a given date, or state images whose scale was adjusted to reflect its relative contributions to international emigration flows or to military movements, for example, would help readers understand the systemic implications of the data collected. Given the importance assigned to migration as an engine of cultural change, maps of migration potential might be created, distinguishing

9. M.C. Ricklefs et al., A New History of Southeast Asia (Houndsmills, 2010).

ı०. A. Ota, "Toward Cities, Seas, and Jungles: Migration in the Malay Archipelago, c. 1750I 850 ", in Lucassen and Lucassen, Globalising Migration History, pp. I80-2 I 4; M. Mazard, "The Art of (Not) Looking Back: Reconsidering Lisu Migrations and 'Zomia'", in ibid., pp. 2 I 5-246; J. Scott, The Art of Not Being Governed: An Anarchist History of Upland Southeast Asia (New Haven, CT, 2009).

I I. J. Lucassen, Migrant Labour in Europe, I600-1900: The Drift to the North Sea (London, 1987); A. McKeown, Chinese Migrant Networks and Cultural Change: Peru, Chicago, Hawaii, 1900-1936 (Chicago, IL, 200I); S. Amrith, Crossing the Bay of Bengal: The Furies of Nature and the Fortunes of Migrants (Cambridge, MA, 2013); see also L.P. Moch, Moving Europeans: Migration in Western Europe since I650 (Bloomington, IN, 2003). 
low- from high-density regions while plotting distance and transportation options. ${ }^{{ }^{2} 2}$ Even if the CCMR comes in a state-sized package, migration cannot be contained within a national boundary. Going global requires not only comparison, but also linkage, shown more effectively in pictures than in words.

The issue of linkage raises the question of whether basic units within which migration is measured ought to be expanded. As the generators of data, states have consolidated their hold on scholarly attention, but empires also collected statistical information on their populations, admittedly more systematically in the modern period unless a state was also a territorial empire. As the articles by Bosma, van Lottum, and Umeno in Globalising Migration History demonstrate, much military movement, international migration, plantation recruitment, and colonization takes place within imperial networks rather than nation states, and understanding such movements requires moving beyond individual state-level data to at least information on other states involved in the same migration system. ${ }^{13}$ For much of Eurasia in the early modern period, when mercantilist ideas tended to shape trade and migration policies, movements within empires had a legitimacy denied to exodus to another state. The extent to which European states in the aggregate constituted a migration system, in comparison to circulations within Spanish, Portuguese, French, British, and Dutch empires, is an important research question. By adding attention to imperial boundaries, the major Eurasian empires, including territorial empires such as China and Russia, become comparable to one another as well as to territorial empires such as China and Russia, rather than collections of individual political units. This is a particularly fraught question for the case of the South Asian subcontinent, where multiple empires succeeded one another before the creation of India and Pakistan and shared territory with several small states. CCMR rests on a typology that requires a state boundary to delineate much of the movement counted. If the composition of types of migration matters more than its overall quantity, borders which differentiate emigration and immigration from other types of internal circulation become very important. There are alternative ways to conceptualize and name boundaries. Sunil Amrith describes his research as movement from South India around the Bay of Bengal to Burma, Ceylon, and Malaya, but relabeling it as circulation from British India to various sister colonies in Southeast Asia changes substantially the interpretive

I2. See Jan de Vries, European Urbanization, I500-I800 (London, I984).

I 3. U. Bosma, "Migration and Colonial Enterprise in Nineteenth Century Java", in Lucassen and Lucassen, Globalising Migration History, pp. I I-I79; J. van Lottum, "Migration in an Age of Change: The Migration Effect of Decolonization and Industrialization in Indonesia, c.19002000", in ibid., pp. 247-275; Y. Umeno, "Han Chinese Immigrants in Manchuria, I $850-1931$ ", in ibid., pp. 307-334. 
vantage point. ${ }^{14}$ Explanations of global migration history will look different if empires, as well as states, are considered building blocks and explored as alternative frameworks channeling mobility.

The Lucassens's typology and calculated CCMRs make an impressive contribution to migration research and social science history, facilitating global comparisons of a basic social process as it changed over time. But what they outline is a starting point, rather than the end of the story. 